\title{
Certain Aspects of the Financial Security of the Region on the Example of the Krasnoyarsk Territory (Krai)
}

\author{
Tatiana S. Zimniakova* \\ Siberian Federal University \\ 79 Svobodny, Krasnoyarsk, 660041, Russia
}

Received 27.08.2015, received in revised form 14.09.2015, accepted 20.10.2015

New foreign policy conditions rise the issues of the economic security of the country and its regions. Most researchers propose to determine the level of the economic security of the region basing on the comparison of a number of indicators with the threshold values determining the "reference standard" of the region's economy. We do not consider any deeper trends that define the current and future state of the region's economy. The article uses the Krasnoyarsk Territory (Krai) as an example to analyze the dynamics of certain aspects of the financial security that are the threat source for the economic security of the region in general. A deeper analysis of two aspects, the state of the region's banking system and the financial sustainability of the population, has allowed to determine the threat sources for the state of the socio-economic system of the region.

Keywords: economic security of the region, financial security of the region, regional banks, household's finances, loan debt.

DOI: 10.17516/1997-1370-2015-8-11-2385-2397.

Research area: economics.

In the situation of the economic crisis caused by the instability of the foreign policy, the issues related to the economic security of the country are currently very important. Moreover, changes in the Russian economy in recent years demand a revision of theoretical tools and methodological approaches to the economic security.

The problem of the economic security has been studied by Russian economists since 80-90ies of the last century. During this time, they have proposed several options for interpretation of this concept (L. Abalkin, V. Senchagov, G. Gutman, A.
Gorodetsky, A. Arkhipov et al.). They developed a method of calculation of the economic security indicators, as well as a classification of threats to the national economy.

Most researchers agree that the economic security of the region is such "a state of the regional socio-economic system when it can be characterized by sustainable development, and the ability to respond adequately and effectively to all critical threats, and ensure the possibility to achieve sustainable development of the country as a whole" (Prianikova A.G., 2012, p. 32).

(C) Siberian Federal University. All rights reserved

* Corresponding author E-mail address: tzimnyakova@inbox.ru 
The level of the economic security is usually assessed on the basis of a comparison of a number of socio-economic indicators with threshold values (Abalkin L.I., 2000, p. 645, Prianikova A.G., 2012, p. 146). However, in the course of such an assessment not enough attention is paid to the trends in the development of the regional socio-economic system and the factors that are the source of threats to its security.

We suggest that certain aspects of the financial security of the Krasnoyarsk Territory (Krai) should be evaluated as an example to demonstrate the importance of a deeper analysis of these factors. We have selected two components of the financial system in the region for the review: the banking system and the finances of the region's population. The study was conducted with the support of the Krasnoyarsk Regional Fund of Science and Technical Activity Support under the project "Methods of Designing the System of Regular Observations and Expert-analytical Assessment of the State of the Economy, Innovation Complex and Social Sphere of the Krasnoyarsk Territory (Krai) with the Development and Disclosure of the Thematic Bulletin".

\section{Regional credit institutions and the economic security of the region}

The banking system in the region contributes significantly to its economic security. The high level of the banking sector development allows to meet the needs of the region's business entities in banking services, which creates conditions for the sustainable economic growth, and major regional banks may act as partners of the government to fulfill joint programmes aimed at solving strategically important tasks (support for small business, development of mortgage lending, etc.).
In order to understand the extent to which the banking system of the Krasnoyarsk Territory (Krai) corresponds to the interests of the economic security of the region, let us analyze two aspects: the general state of the banking sector and the condition of the regional credit institutions (hereinafter referred to as $\mathrm{CI}$ ).

The overall development of the banking sector in the region can be assessed using the index of availability of banking services according to the method proposed by the Bank of Russia. This index evaluates the development of the banking system in the region in three areas: institutional development; the level of saturation of the territory with credits; the level of development of the savings industry (Otchet o razvitii banrovskogo sectora, 2015). The evaluation of these three areas is reduced to a total average index that is relative, i.e. it demonstrates the development of the banking system in the region in comparison with the situation nationwide. Therefore, if the total index of the region is less than 1 , then the level of the development of the banking system in the region is lower than in Russia as a whole.

In 2014, the total average index of the availability of banking services in the Krasnoyarsk Territory (Krai) was 0.86 (Table 1), i.e., the level of the development of banking in the region is worse than nationwide, less than 1. However, in the Siberian Federal District, it is the second figure after the Kemerovo and Novosibirsk regions and is slightly larger than the index calculated for the SFD as a whole. At the same time, if we estimate the dynamics of the index calculated for the Krasnoyarsk Territory (Krai), we can note its growth over the last four years (Fig. 1).

The weak point in the availability of banking services in the Krasnoyarsk Territory (Krai) is the level of development of the savings industry. In 2014 , it was 0.66 , or $66 \%$ of the 
All-Russian level (Table 1). This means that given a sufficiently large number of banks in the region (institutional saturation in 2014 was 1.1), the population of the region are less likely to keep their savings in banks than in nationwide (Table 1). This situation is also typical for other regions of the Siberian Federal District, with the exception of the Novosibirsk region (Oblast') and Tomsk region (Oblast'), where the index of the savings industry is quite high (0.98 and 0.86 , respectively) (Table 1).

In general, the level of availability of banking services in the Krasnoyarsk Territory (Krai) is quite satisfactory with positive dynamics.

Now let us consider the situation of the regional $\mathrm{CI}$ in the banking system of the region,

Table 1. The Index of the Availability of the Banking Services in the Regions of the Siberian Federal District in 2014

\begin{tabular}{|l|c|c|c|c|}
\hline \multicolumn{1}{|c|}{ Region } & $\begin{array}{c}\text { The index of } \\
\text { the institutional } \\
\text { saturation }\end{array}$ & $\begin{array}{c}\text { The index of } \\
\text { the financial } \\
\text { saturation }\end{array}$ & $\begin{array}{c}\text { The index of the } \\
\text { savings industry } \\
\text { development }\end{array}$ & $\begin{array}{c}\text { Total average } \\
\text { index }\end{array}$ \\
\hline Siberian Federal District & 0.96 & 0.93 & 0.68 & $\mathbf{0 . 8 5}$ \\
\hline Altai Republic & 0.95 & 1.24 & 0.4 & $\mathbf{0 . 7 8}$ \\
\hline Republic of Buryatia & 1.18 & 1.26 & 0.39 & $\mathbf{0 . 8 4}$ \\
\hline Tuva Republic & 0.72 & 1.15 & 0.32 & $\mathbf{0 . 6 4}$ \\
\hline Republic of Khakassia & 1.07 & 0.66 & 0.47 & $\mathbf{0 . 6 9}$ \\
\hline Altai Territory & 0.78 & 1.02 & 0.58 & $\mathbf{0 . 7 7}$ \\
\hline Zabaikalsky Territory & 0.96 & 0.75 & 0.45 & $\mathbf{0 . 6 9}$ \\
\hline Krasnoyarsk Territory (Krai) & 1.1 & 0.89 & 0.64 & 0.86 \\
\hline Irkutsk Region (Oblast') & 0.97 & 0.81 & 0.74 & $\mathbf{0 . 8 4}$ \\
\hline Kemerovo Region(Oblast') & 0.81 & 1.44 & 0.72 & $\mathbf{0 . 9 5}$ \\
\hline Novosibirsk Region(Oblast') & 0.97 & 0.91 & 0.98 & $\mathbf{0 . 9 5}$ \\
\hline Omsk Region(Oblast') & 1 & 0.73 & 0.59 & $\mathbf{0 . 7 6}$ \\
\hline Tomsk Region (Oblast') & 1.01 & 0.6 & 0.86 & 0.81 \\
\hline
\end{tabular}

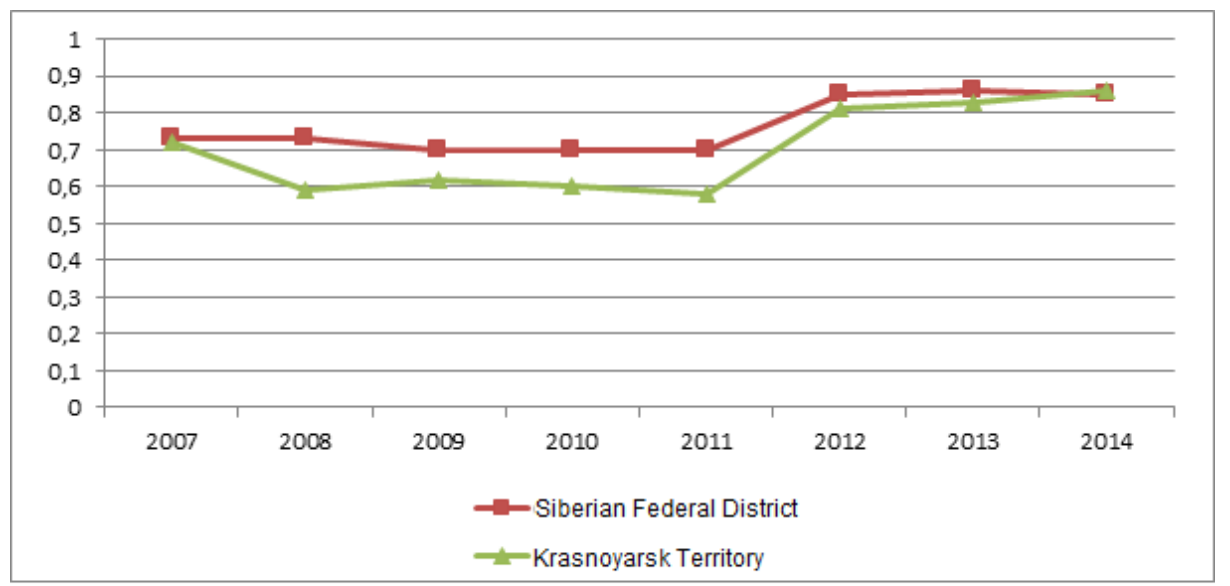

Fig. 1. Dynamics of the index of availability of banking services in the Krasnoyarsk Territory (Krai) and the Siberian Federal District 
from the general concept of "banking services" we will move to certain entities that provide these services in the region.

Currently, there are 5 credit institutions based in the region and 30 credit institutions based outside the region that operate in the Krasnoyarsk Territory (Krai). Five regional credit institutions include (by descending of assets) Joint Stock Commercial Bank Kedr, Joint Stock Investment Commercial Bank Eniseisk United Bank Ltd., Joint Stock Commercial Bank Yenisei, Commercial Bank Kansky, Limited Liability Company Non-Bank Credit Organization Krasnoyarsk Territorial Settlement Center (Table 2).

Joint Stock Commercial Bank Kedr occupies the leading positions among regional credit institutions. In 2014, it came under control of B\&N Bank (78.75\% of the equity capital).

The vast majority of the assets and the bank "activity" in the region belongs to the large federal banks: Savings Bank of Russia, VTB, Alfa-Bank.

The role of regional credit institutions in the financial market of the Krasnoyarsk Territory (Krai) has been steadily decreasing. This trend is typical for most regions in Russia: out of 815 banks represented in the ranking of Banki.ru website by the net assets as of February 01, 2015,
446 credit institutions are registered in Moscow and the Moscow region (Reiting bankov Rossii, 2015). Their total net assets account to nearly 64 trillion RUB or more than $80 \%$ of the total net assets of all banks represented in the rankings (Reiting bankov Rossii, 2015). Few regions in Russia have large banks with a federal network of branches that are registered in the region. Such regions are, for example, St. Petersburg (VTB), Tatarstan (AkBars), Novosibirsk (MDM Bank).

The high density of banking institutions in the same financial center is not typical for developed countries. For example, in Germany regional banks with an extensive network in the region play a very important role.

In the Krasnoyarsk Territory (Krai), as it has been already mentioned, there are five regional operating credit institutions. At one time, their number reached 29 (in 1995). Gradually, regional credit institutions are driven out by federal players and banks from other regions.

The share of assets of regional credit institutions of the Krasnoyarsk Territory (Krai) in the total value of assets of credit institutions operating in the region, decreased from $13 \%$ in 2009 to $6 \%$ in 2014 (Fig. 2). The share of regional $\mathrm{CI}$ in the credit market dropped from $11 \%$ to $5 \%$ over the same period (Fig. 2).

Table 2. The Main Indicators of the Regional Banks' Activities in the Krasnoyarsk Territory (Krai) in 2014, mln. RUB (Otchetnost bankov Rosii, 2015)

\begin{tabular}{|l|c|c|c|c|}
\hline \multicolumn{1}{|c|}{ Bank } & Assets & $\begin{array}{c}\text { Outstanding } \\
\text { loans }\end{array}$ & $\begin{array}{c}\text { Obtained funds } \\
\text { of individuals }\end{array}$ & $\begin{array}{c}\text { Retained } \\
\text { profits/ loss }\end{array}$ \\
\hline Joint Stock Commercial Bank Kedr & $27,626.36$ & $20,164.27$ & $19,522.54$ & 521.57 \\
\hline $\begin{array}{l}\text { Joint Stock Investment Commercial Bank } \\
\text { Eniseisk United Bank Ltd. }\end{array}$ & $4,598.15$ & $3,127.52$ & $2,505.61$ & 16.95 \\
\hline Joint Stock Commercial Bank Yenisei & $2,874.66$ & $1,860.61$ & $1,355.52$ & 16.49 \\
\hline Commercial Bank Kansky & $1,937.27$ & $1,572.35$ & $1,526.26$ & -28.80 \\
\hline $\begin{array}{l}\text { Limited Liability Company Non-Bank } \\
\text { Credit Organization Krasnoyarsk } \\
\text { Territorial Settlement Center }\end{array}$ & 207.96 & 0 & & 7.86 \\
\hline
\end{tabular}




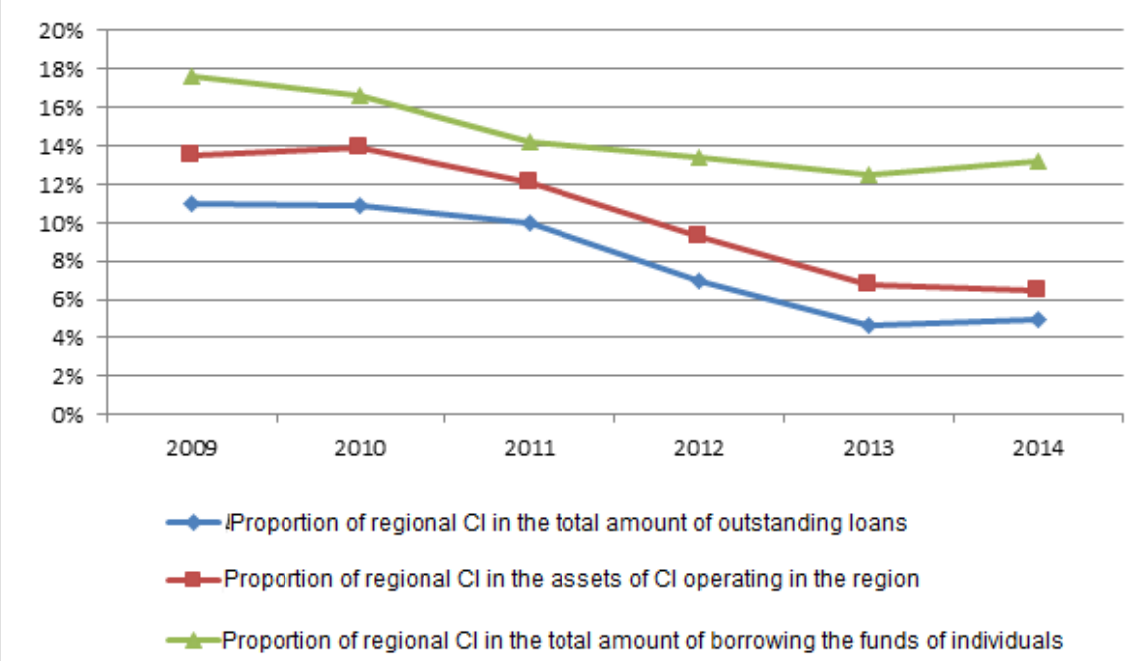

Fig. 2. Regional Banks of the Krasnoyarsk Territory (Krai) in the Market of Credits and Deposits of Individuals

At the same time, regional CI are more active in attracting deposits from the population than those based outside the region: the proportion of borrowed funds from the customers in the assets of regional credit institutions as of January 01, 2015 , is $65 \%$, while for the out-of-region credit institutions the share is only $29 \%$ (Table 3 ). The overall proportion of regional credit institutions in the market of deposits of individuals in the region is quite significant and amounts to $13 \%$ (Fig. 2). Thus, regional credit institutions make a significant contribution to the savings industry of the region.

The aggravation of regional banks' situation is a negative factor for the economic security of the region: the vast majority of financial assets accumulated in the region is under the control of credit institutions in Moscow and other regions.

The region tried to strengthen the position of regional credit institutions in 2001: the Resolution No. 64-P of the Regional Administration proposed measures to support the regional $\mathrm{CI}$ based on the analysis of the situation in the banking sector of the region. However, the change of the political situation in the region and the country did not allow to implement the proposed measures (Postanovlenie № 64-П от 29.01.2001).

In summary, it can be noted that with quite an adequate level of overall development of the banking sector of the Krasnoyarsk Territory (Krai), the position of regional banks is one of the threats to the economic security of the region. Firstly, this is due to the fact that a large part of the banking sector in the region is controlled by credit institutions from other regions (mostly from the Moscow one). Secondly, the region misses the opportunities of the territory development related to the benefits of the local CI, i.e. flexibility, speed of decision-making, better knowledge of the region and its businesses.

Often, regional CI occupy a unique niche in the banking market, in which the players from other regions are unable to compete. This fact is illustrated by the significant proportion of banks in the regional market of deposits of individuals: $13 \%$, despite the fact that the assets of the regional CI make only $6 \%$ of the total assets of credit institutions in the region (Table 3).

Therefore, the support of regional CI by local authorities may contribute significantly to the economic security of the region. 
Table 3. Comparison of the Indicators of Regional and Out-of-region Credit Institutions of the Krasnoyarsk Territory (Krai) (Biulleteni Banka Rossii, 2015)

\begin{tabular}{|c|c|c|c|c|c|}
\hline Indicator & 2010 & 2011 & 2012 & 2013 & 2014 \\
\hline $\begin{array}{l}\text { Assets of credit institutions operating in the region, } \\
\mathrm{mln} \text {. RUB }\end{array}$ & 218,767 & 233,186 & 298,690 & 433,723 & 567,323 \\
\hline Proportion of regional CI, $\%$ & $13 \%$ & $14 \%$ & $12 \%$ & $9 \%$ & $7 \%$ \\
\hline $\begin{array}{l}\text { Outstanding loan of CI operating in the region, mln. } \\
\text { RUB }\end{array}$ & 182,999 & 202,693 & 263,953 & 390,137 & 517,711 \\
\hline Proportion of regional CI, $\%$ & $11 \%$ & $11 \%$ & $10 \%$ & $7 \%$ & $5 \%$ \\
\hline $\begin{array}{l}\text { Borrowed funds of individuals of CI operating in } \\
\text { the region, mln. RUB }\end{array}$ & 86,360 & 107,248 & 131,897 & 172,705 & 196,185 \\
\hline Proportion of regional CI, $\%$ & $18 \%$ & $17 \%$ & $14 \%$ & $13 \%$ & $13 \%$ \\
\hline Borrowed funds of individuals in the total assets: & - & - & - & - & - \\
\hline Proportion of regional CI, $\%$ & $55 \%$ & $52 \%$ & $58 \%$ & $64 \%$ & $65 \%$ \\
\hline Proportion of out-of-region CI, \% & $45 \%$ & $43 \%$ & $38 \%$ & $32 \%$ & $29 \%$ \\
\hline
\end{tabular}

\section{Financial security of the region's population}

One of the aspects of financial security of the region is the state of finances of its population.

Under the financial security of the population we understand such a state of household finances, when the level of income and other resources is sufficient to protect the interests of people and allows to maintain financial stability in the moment and in the future. In other words, the financial security of the population assumes that households have sustainable budgets able to cope with the load of obligatory payments and provide their current and future needs.

The household budget is formed by income and expenditure in money and in kind. Official statistics monitors the money income and expenditure of the population, so there is a possibility of using official statistics to calculate the average money household budget in the region for a month and to analyze it in terms of financial security.

Thus, in 2014 the average budget of a household in the Krasnoyarsk Territory (Krai) included money income in the amount of 63,324
RUB and money expenditure in the amount of 65,775 RUB per 1 month (Table 4).

Money income of the average household decreased in 2014 in comparison to 2013 by $2 \%$ and became lower than the money income by 2,450 rubles per month. Herewith, money expenditure maintained a positive trend and increased in comparison with 2013 year by $4 \%$.

It is for the first time in the past 12 years when such a situation occurred. Even during the crisis of 2008, the money income of the population of the Krasnoyarsk Territory (Krai) were significantly higher than the expenditure (see Fig. 3).

The excess of money expenditure over income means that the consumption is financed by reducing the accumulated assets of households. I.e. under the conditions of urgent reduction in money income in 2014, the population was not ready to reduce their expenditure correspondingly and used their savings from previous years to cover the expenditure.

Let us consider the changes that has occurred in recent year in the structure of income and expenditure of the households in the Krasnoyarsk Territory (Krai). 
Table 4. Calculation of indictors of the monthly budget of an average household in the Krasnoyarsk Territory (Krai) in 2014.

\begin{tabular}{|l|c|}
\hline \multicolumn{1}{|c|}{ Indicator } & Value \\
\hline Number of households in the region & 1,097 \\
\hline Average size of the household & 2.7 \\
\hline Money expenditure of the region's population, mln. RUB & 833,602 \\
\hline Average money income per a household per month, RUB & 63,324 \\
\hline Money expenditure of the region's population, mln. RUB & 865,858 \\
\hline Average money expenditure per a household per month, RUB & 65,775 \\
\hline
\end{tabular}

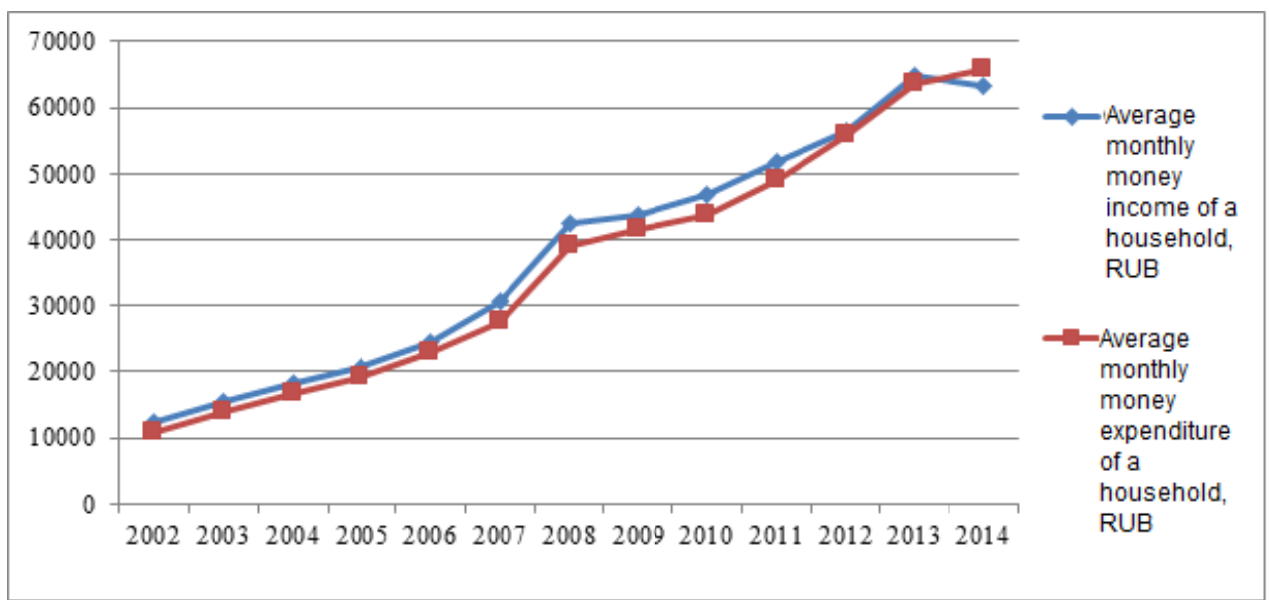

Fig. 3. Dynamics of the monthly money income and expenditure calculated per one household in the Krasnoyarsk Territory (Krai)

Over the past 13 years the proportion of social payments as part of money income has significantly increased: from $11.9 \%$ in 2002 to $19.9 \%$ in 2013 (see Fig. 4). At the same time the proportion of the income from business activities decreased by $0.7 \%$, the property income decreased by $4.8 \%$, as well as the employment income decreased by $5.5 \%$.

Such dynamics shows the increase of dependence of household budgets in the region from public subsidies, while the proportion of income from employment and business activities is reducing.

The structure of expenditure of the region's population also underwent some changes from
2000 to 2013 (see Fig. 5): the share of expenditure on goods and services significantly increased (10.1\%). The share of spending on the acquisition of financial assets declined significantly (by $18.4 \%$ ). Thus, today the population of the Krasnoyarsk Territory (Krai) prefer to spend money on current consumption rather than investment in financial assets if compared to 2000 .

The share of expenditure on property acquisition grew inconsistently: from insignificant $0.2 \%$ in 2000 to $3.5 \%$ in 2013 . But obligatory and other payments grew continuously and increased from $8.7 \%$ in 2000 to $14 \%$ in 2013 .

Let us recall that the household budget can be called sustainable if income sources are stable and 


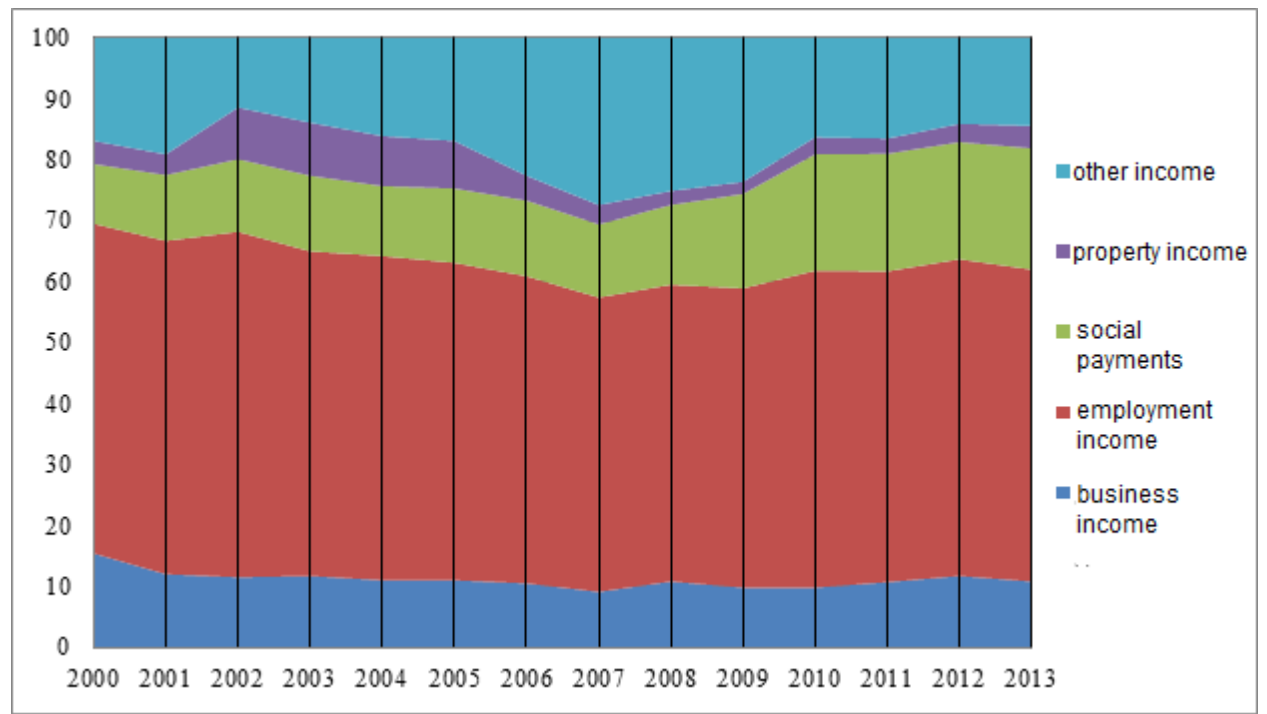

Fig. 4. The structure of money income of the population in the Krasnoyarsk Territory (Krai), \%

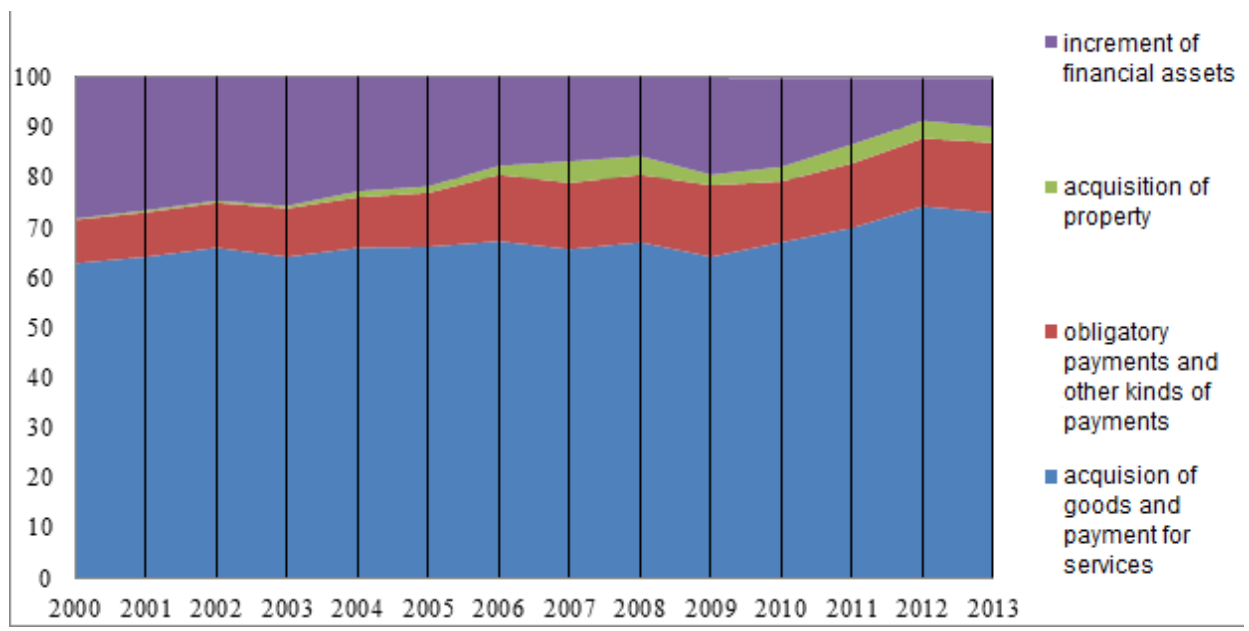

Fig. 5. Structure of money expenditure of the population of the Krasnoyarsk Territory (Krai), \%

allow regular and full payment of obligatory payments and maintain an acceptable standard of living of the household. Moreover, the dynamics of the household income must cover the inflationary increase of expenditure.

Real money income of the household in the region $^{1}$ showed a decrease in 2014 by $7.4 \%$ (see Fig. 6).

The decrease of real money income of household in 2014 (7.4 \%) was even more significant than in the crisis of 2008 (5.7\%). But there will be no quick correction like back in 2009. Under the conditions of the ongoing economic crisis the tendency of the decrease in real money income of the population may continue endangering the sustainability of households.

Besides the sustainability of income sources, the adequate burden of all sorts of payments is important for the household budget, while it 


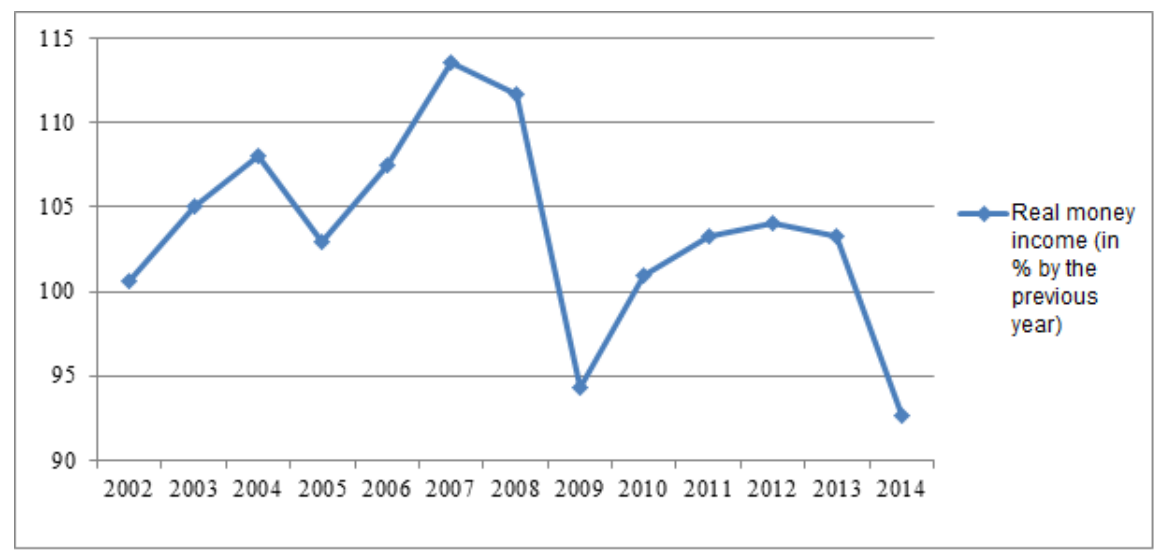

Fig. 6. Real money income of the population of the Krasnoyarsk Territory (Krai) in \% by the previous year

Table 5. Indicators of the average monthly budget of the household in the Krasnoyarsk Territory (Krai) in 2014.

\begin{tabular}{|l|c|c|}
\hline \multicolumn{1}{|c|}{ Indicator } & Value & $\begin{array}{c}\text { Proportion in the income } \\
\text { of the household, } \%\end{array}$ \\
\hline The average balance of debt per household, RUB & 265,580 & \\
\hline Monthly money income of the household, RUB & 63,324 & \\
\hline Monthly money income of the household, RUB & 65,775 & \\
\hline Monthly disposable income of the household, RUB & 53,705 & \\
\hline Monthly obligatory payment of the household, RUB & 9,619 & 15 \\
\hline Monthly loan payments, RUB & 7,335 & 12 \\
\hline Monthly minimum cost of living of the household, RUB & 24,802 & 39 \\
\hline $\begin{array}{l}\text { Balance after payment of all compulsory payments, loan payments, } \\
\text { maintenance of the cost of living per month, RUB }\end{array}$ & 21,568 & 34 \\
\hline
\end{tabular}

allows to provide a decent standard of life for the members of the household.

The first kind of such a burden on the household budget includes mandatory payments, such as taxes and other compulsory payments. According to estimates, this amount in the monthly budget of the average household in the region in 2014 was 9,619 rubles or $15 \%$ of the money income (see Table 5). In accordance with the world standards, it is not so much: the US tax burden varies between $30-50 \%$ depending on the state.

However, the share of obligatory payments in the expenditure of the population of the region has increased in recent years (see Fig.
5), and may continue to rise with the intentions of the Russian Government to increase the rates of the income tax and taxes on personal property.

The next type of the burden on the household budget includes loan payments or loan burden. Active use of bank loans by the population of the Krasnoyarsk Territory (Krai) in the last decade has increased significantly. The balance of the outstanding loans of individuals owed to credit institutions increased by 43 times in 2014 compared to 2003 (see Fig. 7).

During 2014 the balance of the debt of population in the region to credit institutions decreased by $22 \%$ compared to 2013 . The 


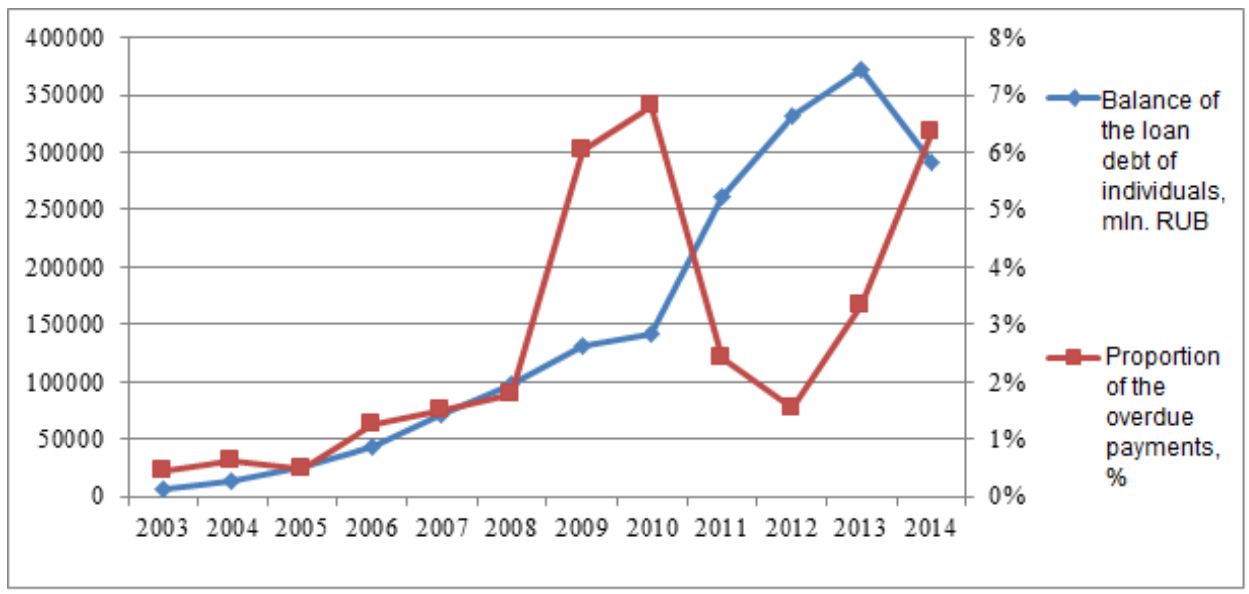

Fig. 7. Dynamics of the balance of debts of the population in the Krasnoyarsk Territory (Krai) owed to credit institutions and the proportion of the overdue payments (Biulleteni Banka Rossii, 2015)

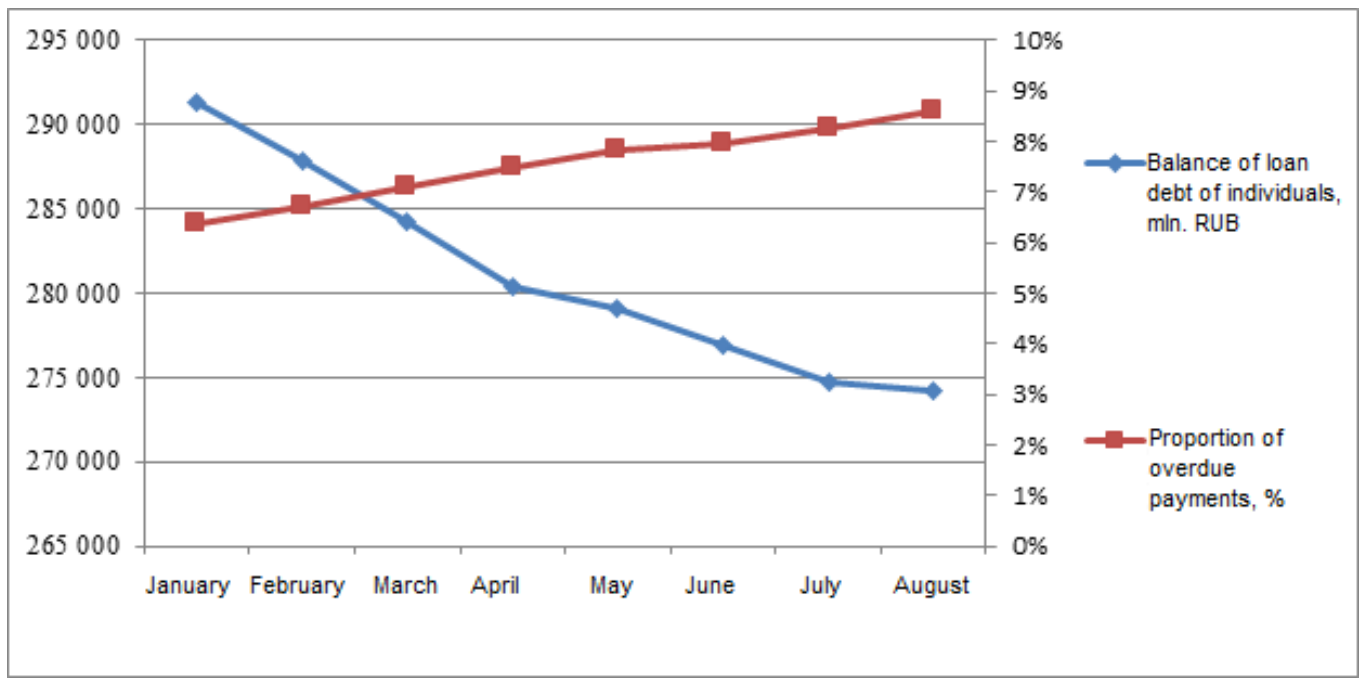

Fig. 8. Dynamics of the outstanding loans of the population in the Krasnoyarsk Territory (Krai) owed to the credit institutions and the proportion of the overdue payments in 2015 (Biulleteni Banka Rossii, 2015)

main reason is the crisis and higher interest rates that lowered the interest of borrowers. Simultaneously, the share of the overdue payments increased significantly: from $3 \%$ in 2013 to $6 \%$ in 2014. And this growth continued in 2015 (see Fig. 8).

Such dynamics of the share of the overdue payments may indicate excessive loan burden on household budgets.
The total outstanding loan balance of individuals in the region at the end of 2014 amounted to $291,341 \mathrm{mln}$. rubles or $23 \%$ of the gross regional product of the region. For comparison, in the US the proportion of outstanding loans on consumer and mortgage loans in 2012 amounted to $78 \%$ of GDP.

However, loans in Russia are issued under higher interest rates, thus servicing of these loans 
Table 6. Regions of the Russian Federation with the high number of citizens unable to withstand the loan burden

\begin{tabular}{|l|c|}
\hline \multicolumn{1}{|c|}{ Region } & $\begin{array}{c}\text { Amount of resident unable to } \\
\text { withstand the loan burden, } \\
\text { thousands people }\end{array}$ \\
\hline Moscow & 42.02 \\
\hline Moscow region (Oblast') & 33.87 \\
\hline Krasnodar Territory (Krai) & 27.98 \\
\hline Sverdlovsk Region (Oblast') & 24.96 \\
\hline Rostov Region (Oblast') & 20.03 \\
\hline Saint-Petersburg & 18.35 \\
\hline Bashkortostan & 17.7 \\
\hline Krasnoyarsk Territory (Krai) & 17.02 \\
\hline Chelyabinsk region (Oblast') & 16.3 \\
\hline Irkutsk region (Oblast') & 15.47 \\
\hline
\end{tabular}

costs more and the burden on household finances is higher.

It is easy to calculate that by the end of 2014, the balance of the outstanding loan per a household accounted in average to 265,580 rubles (see Table 5). Considering that the majority of loans are issued to individuals for the period longer than 3 years (mainly for 5 years), and the average rate on the issued personal loans is about $22 \%$ (Biulleteni Banka Rossii, 2015), then the calculated monthly loan payment per a household will be 7,335 RUB.

Thus, the loan burden of households in the Krasnoyarsk Territory (Krai) is $12 \%$ of the money income of the household or $14 \%$ of the disposable income ${ }^{3}$. For comparison, in the US debt burden on the disposable income did not exceed $10 \%$ in 2012-13 (Vedev, 2014).

The debt burden of $12 \%$ is an the average rate calculated per a household. Active borrowers by some estimates can have up to $50 \%$ of the disposable income (Vedev, 2014).

The unreasonable level of the loan burden implies high risks not only for the household budget, but also for the sustainability of the banking system. Moreover, instead of stimulating the economic growth, bank loans become a source of social problems.

According to RBC (Mikhailova \& Poliakova, 2015) in 2014, the Krasnoyarsk Territory (Krai) entered the top ten regions with the highest number of residents, who are unable to withstand the loan burden (see Table 6).

The pressure related to loaning should be reduced by the Law on the bankruptcy of individuals that entered into force on October 01, 2015 (Mikhailova \& Poliakova, 2015).

Critics of the Law on the bankruptcy of individuals point to its numerous shortcomings, however, agree with the supporters of the Law about the necessity of its adoption in the current situation.

Thus, the average regional household that in 2014 paid tax and loan payments, should have at its disposal about 46,370 rubles to provide the living of all its members (see Table 2). This is more than it is needed to maintain the cost of living of the household (see Table 2), which is undoubtedly a positive fact.

Therefore, by the end of 2014 the average household budget copes with tax and loan burden, 
but also provides the standard of living of the average household above the poverty line.

However, the trends described above threaten the financial "health" of household budgets: decrease of the real incomes of the population, the growth of the tax and loan burden are major risk factors for the financial security of the population.

\section{Conclusion}

Summing up the analysis given above, we can say that the financial aspects of the economic security of the region can actually be a source of threats to the security of the regional economy. The state of the regional loan system and the stability of finances of the population should be considered as part of the factors affecting the economic security of the region as a whole. At the same time, the indicators characterizing the financial aspects of the above should be considered in dynamics, in order to identify negative trends before the crisis phenomena occur in the region's economy.

\footnotetext{
Real money income are money income calculated with consideration of real prices for goods and services Preliminary data of Krasnoyarsk Statistics Service

Disposable income is an income that remains after payment of obligatory and other payments
}

\section{References}

Abalkin, L.I. Trudy Vol'nogo ekonomicheskogo obshchestva Rossii. [Proceedings of the Free Economic Society of Russia]. Moscow, Economica, 2000, vol. 4, 912 p.

Biulleteni Banka Rossii [The Bank of Russia bulletins], available at: http://finansist-kras.ru/cb (accessed 28 July 2015).

Federalny zakon o vnesenii izmenenii v Federalnyi Zakon o nesostoiatel'nosty i bankrotstve [Federal Law on Amending the Federal Law on Insolvency and Bankruptcy] 29.12.2014 № 476-Ф3, available at: http://www.consultant.ru/document/cons_doc_LAW_172973/(accessed at 5 October 2015).

Mikhailova A. Poliakova Iu. Begstvo ot kreditorov [Fleeing from Creditors], RBC Daily, 2015, available at: http://www.rbcdaily.ru/economy/562949997425791

Otchet o razvitii banrovskogo sectora i bankovskogo nadzora v 2014 godu (The Report on the Development of the Banking Sector and Banking Supervision in 2014), available at: www.cbr.ru/publ/ archive/root_get_blob.aspx?doc_id=9878 (accessed 25 July 2015).

Otchetnost bankov Rosii (Russian banks statements), available at: http://kuap.ru/banks/Russia (accessed 30 July 2015).

Postanovlenie Administratsii Krasnoiarskogo kraia O bankovskoi sisteme Krasnoiarskogo kraia №64-П от 29.01.2001 (The resolution No.64-P of the Krasnoyarsk Territory Administration About the banking system of the Krasnoyarsk Territory (Krai)), Available at: http://docs.cntd.ru/ document/985003915 (accessed 26 July 2015).

Prianikova A.G. Statiaticheskoe issledovanie economicheskoi bezopasnosti regionov RF [Statistical Study of the Economic Security of the Regions of RF] Moscow, Gosudarstvenny Universitet Upravleniia, 2012. 238 p.

Reiting bankov Rossii [Russian banks rating], available at: www.banki.ru/news/ daytheme/?id=7766222 (accessed 27 July 2015).

Vedev A. Dolgovoe rabstvo [Debt slavery], RBC Daily, 2014, available at: http://www.rbcdaily.ru/ finance/562949992116455. 


\title{
Отдельные аспекты \\ финансовой безопасности региона \\ на примере Красноярского края
}

Т.С. Зимнякова

Сибирский федеральный университет Россия, 660041, Красноярск, пр. Свободный, 79

\begin{abstract}
Новые внешнеполитические условия актуализируют вопросы анализа экономической безопасности страны и ее регионов. Большинство исследователей предлагают определять уровень безопасности экономики региона на основе сравнения ряда показателей с пороговыми значениями, определяющими «эталон» экономической безопасности. При этом не рассматриваются более глубокие тенденции, которые определяют текущее и будущее состояние экономики региона. В настоящей статье на примере Красноярского края анализируется динамика отдельных аспектов финансовой безопасности, являющихся источником угроз для экономической безопасности региона в иелом. Более глубокий анализ двух аспектов-состояния банковской системы региона и устойчивости финансов населения позволил выявить источники угроз для состояния сочиально-экономической системы региона.
\end{abstract}

Ключевые слова: экономическая безопасность регона, финансовая безопасность региона, региональные банки, финансы домохозяйств, кредитная нагрузка.

Научная спечиальность: 08.00.00 - экономические науки. 